\title{
Understanding the gender gap in immigrant entrepreneurship: a multi-country study of immigrants' embeddedness in economic, social, and institutional contexts
}

\author{
Steven A. Brieger • Michael M. Gielnik
}

Accepted: 1 November 2019 / Published online: 13 January 2020

(C) The Author(s) 2020

\begin{abstract}
Given the rising rate of migration across the globe, immigrant entrepreneurship is more than ever a topic of high theoretical and practical relevance. Immigrant entrepreneurship can offer host societies a win-win situation, generating incomes for immigrant entrepreneurs and contributing to knowledge transfer, innovativeness, and economic growth within the host economy. However, studies reveal that immigrant entrepreneurship is primarily male dominated and our understanding of the drivers and contextual factors that explain the gender gap is limited. Based on the mixed embeddedness approach, this multi-country study investigates the effects of immigrants' embeddedness in supportive economic, social, and institutional environmental conditions on the gender gap in immigrant entrepreneurship. Our key findings are threefold: First, the results confirm that a gender gap in immigrant entrepreneurship exists. Female immigrants, compared with their male counterparts, are less likely to start and run their own business. Second, the results reveal that female immigrant entrepreneurship is encouraged by a supportive entrepreneurial environment, showing that policy
\end{abstract}

\footnotetext{
S. A. Brieger $(\bowtie)$

University of Sussex Business School, University of Sussex, Brighton, UK

e-mail: s.a.brieger@sussex.ac.uk

M. M. Gielnik

Institute of Management and Organization, Leuphana University of Lüneburg, Lüneburg, Germany

e-mail: michael.gielnik@leuphana.de
}

can enhance female immigrant entrepreneurship through supportive conditions. Third, we find the same pattern of results for forced immigrants and opposite results for natives, suggesting that entrepreneurship is a "Plan A" employment strategy for (forced) female immigrants, whereas it is only a "Plan B" employment strategy for female natives.

Keywords Immigrant entrepreneurship · Female entrepreneurship · Mixed embeddedness · Multi-country study · Global entrepreneurship monitor · Gender

JEL Classifications $\mathrm{F} 22 \cdot \mathrm{L} 26 \cdot \mathrm{M} 16 \cdot \mathrm{P} 48$

\section{Introduction}

The global number of refugees and internally displaced persons has reached the highest level since World War II. By the end of 2017, the number of refugees, internally displaced persons, and asylum seekers stood at 68.5 million (UN Refugee Agency 2018). Unresolved political, economic, social, and environmental problems may continue to cause migration, begging the question of how immigrants can be integrated into their host societies. One possibility for assimilating immigrants into host societies is integration through entrepreneurship (Aliaga-Isla and Rialp 2013). Entrepreneurship means identifying and exploiting business opportunities (Shane and Venkataraman 2000). A common form of entrepreneurship is starting a new business (Gartner 1985). Starting a new business has a positive effect on 
the immigrant entrepreneur (e.g., through socioeconomic integration) and can also evoke positive societal effects within the host country. Immigrants may bring new and different experiences, perspectives, knowledge, skills, and networks from which the host society can benefit. Immigrant entrepreneurs can thus make significant contributions to knowledge transfer, innovativeness, competitiveness, and economic growth (Baycan-Levent and Nijkamp 2009; Xavier et al. 2012; Marchand and Siegel 2014; Saxenian 2002).

In OECD and European Union countries, approximately $12 \%$ of immigrants have their own business (OECD/European Commission 2015). In these countries, immigrants are mostly more likely to be selfemployed than the native-born population. For example, in Poland and the Czech Republic, more than $25 \%$ of immigrants run their own business - a rate which is nearly two times higher than the rate among their native counterparts (OECD/European Commission 2015). However, a higher rate of entrepreneurship is not evenly distributed among male and female immigrants; rather, there is a gender gap in immigrant entrepreneurship. Entrepreneurial activity among immigrants, or "immigrant entrepreneurship," is mainly a male phenomenon. Female immigrants are, compared with male immigrants, less engaged in entrepreneurial activity — which is commonly attributed to a combination of lower entry rates and higher exit rates (OECD 2011; Fiscal Policy Institute 2012; Lofstrom and Lofstrom 2014; Constant and Zimmermann 2004).

Although a few initial studies have already documented the existence of a gender gap in immigrant entrepreneurship, it has not yet received wide attention in the academic discipline of entrepreneurship. Apart from anecdotal evidence reporting that immigrant women face greater obstacles compared with their male counterparts (Vaccarino et al. 2011; Azmat 2013), neither individual nor contextual factors influencing the gender gap in immigrant entrepreneurship have been systematically examined. Several authors have noted that research has frequently focused on immigrant men as entrepreneurs, whereas female immigrant entrepreneurship has been neglected (Collins and Low 2010; Marchand and Siegel 2014).

The goal of this paper is to advance our understanding of the gender gap in immigrant entrepreneurship. Specifically, we seek to examine contingency factors that explain under which conditions the effect of gender on immigrant entrepreneurial activity is particularly strong or weak. To this end, we build on the concept of mixed embeddedness that integrates aspects of the host country's economic, social, and politicalinstitutional environment, and thus offers a useful framework for understanding the extent to which environments support entrepreneurship (Kloosterman et al. 1999; Rath and Kloosterman 2000; Kloosterman and Rath 2001; Kloosterman 2003; Wang and Warn 2017). In our study, we examine the effect of a supportive environment in terms of the host country's economic (market opportunities and market access), social (migration and government network), and institutional factors (business-friendly regulation and rule of law) on the gender gap in immigrant entrepreneurship. We hypothesize that a supportive environment influences the relationship between gender and immigrant entrepreneurship in such a way that particularly benefits immigrant women. In line with previous research (Vaccarino et al. 2011; Azmat 2013), we argue that immigrant women are in a disadvantaged position and that they are therefore more dependent on a supportive environment. Accordingly, a supportive environment should promote entrepreneurship among immigrant women. Therefore, we hypothesize that there is a smaller gender gap in immigrant entrepreneurship in countries with a more supportive environment for entrepreneurial activity. In addition, we also test our hypotheses with forced immigrants. Forced immigrants - who are displaced by violence and conflicts, environmental disasters, or development-induced re-settlement - tend to be highly vulnerable due to a limited access to necessary resources. Accordingly, we expect that a supportive environment is even more important for forced immigrants.

To test our hypotheses, we use individual- and country-level data from 11,471 immigrants located in 51 countries. Our research contributes to the current debate on immigrant entrepreneurship in a twofold manner. First, following an interactionist approach (Frese and Gielnik 2014; Welter 2010), we discuss and show how a supportive environment enhances entrepreneurial activity among immigrant women. By employing a contextual perspective, our theoretical model thus contributes to a better understanding of the gender gap in immigrant entrepreneurship. Furthermore, we examine the moderating effect of favorable environmental conditions in two additional groups, the subgroup of forced immigrants and native-born individuals to provide a deeper understanding of the role of favorable environmental conditions. Our results show that the moderating 
effect holds for forced immigrants but not for nativeborn individuals. Accordingly, a supportive environment plays a contradictory role for (forced) immigrant and native women. Whereas a supportive environment reduces the gender gap for (forced) immigrants, it increases the gap for natives. These findings add to our theoretical understanding because they suggest that environmental conditions may have different and even contradictory effects for specific subgroups in the population. Finally, by testing our model, we improve the evidence base concerning country-level drivers of immigrant entrepreneurship. Since the current stream of immigrant entrepreneurship literature is primarily based on single-country studies, our study provides novel insights based on large representative data to advance the current state of knowledge on country-level factors influencing immigrant entrepreneurship.

\section{Theoretical background and hypotheses}

The concept of mixed embeddedness has been developed particularly to help understand the complex interactions in which immigrant entrepreneurship takes place (Kloosterman et al. 1999; Kloosterman and Rath 2001; Kloosterman 2003). Specifically, the concept of mixed embeddedness discusses the interplay of characteristics at the individual and contextual levels. The individual level comprises immigrants' gender, age, cultural background, and human, financial, and social capital. The contextual level includes the host country's economic, social, and political-institutional environment, such as market conditions, governmental support, and regulations (Kloosterman and Rath 2001; Kloosterman 2003; Azmat 2010, 2013; Peroni et al. 2016).

Based on the mixed embeddedness perspective (Kloosterman et al. 1999; Kloosterman and Rath 2001; Kloosterman 2003; Azmat 2010), our conceptual framework includes three types of contextual conditions in which immigrants are embedded: economic embeddedness, which comprises the degree to which immigrants are able to find and exploit entrepreneurial opportunities; social embeddedness, which considers social structures, networks, and ties; and institutional embeddedness, which involves laws, rules, and regulations that can be favorable or unfavorable for aspiring immigrant entrepreneurs. Following the logic of an interactionist approach (Frese and Gielnik 2014; Welter 2010), we focus on the interplay of gender and contextual factors in immigrant entrepreneurship. We argue that the context, in terms of economic, social, and institutional factors, functions as a contingency factor influencing the effect of gender on immigrant entrepreneurship. We argue first for the main effect of gender on immigrant entrepreneurship and then theorize about context as a boundary condition that strengthens or weakens the effect of gender on immigrant entrepreneurship. Figure 1 illustrates our conceptual framework.

\subsection{The gender gap in immigrant entrepreneurship}

Research shows that women around the world are, in general, less likely to engage in entrepreneurship than men (Kelley et al. 2015; Minniti and Naudé 2010; Elam and Terjesen 2010; Verheul et al. 2006). The general entrepreneurship literature suggests that the gender gap in entrepreneurship results from individual and contextual factors, such as socio-demographic characteristics, entrepreneurial attitudes, family background, and environmental conditions (Klyver et al. 2013; Kelley et al. 2015; Koellinger et al. 2007; Wagner 2007). Specifically, at the individual level, several studies show that women's entrepreneurial self-efficacy-or the selfassessment of having the required capabilities to start and run a company - is lower than men's (Koellinger et al. 2013; Wilson et al. 2007). Thébaud (2010) states in her analysis that women are about half as likely as men to believe that they have the knowledge, skills, and experience to start a business. The lower level of entrepreneurial self-efficacy among women is not limited by geographic regions or cultural subsets but is rather a global phenomenon independent of contextual variables (Wilson et al. 2007; Minniti and Nardone 2007; Allen et al. 2007). In addition, studies show that women have stronger fear to fail as entrepreneurs and are thus less willing to take risks (Bönte and Piegeler 2013; Wagner 2007; Caliendo et al. 2009). Several authors also identify women's restricted access to financial resources as a reason for the gender gap in entrepreneurship (Muravyev et al. 2009; Heilbrunn 2004; Carter et al. 1997; Fairlie and Robb 2009; Marlow and Patton 2005). Furthermore, research reveals that women, compared with men, have fewer and different social networks (Verheul and Thurik 2001; Koellinger et al. 2013). The lower levels of financial and social resources are also important in explaining why new ventures by women suffer from lower survival rates (van der Zwan et al. 2012; Allen et al. 2007). 


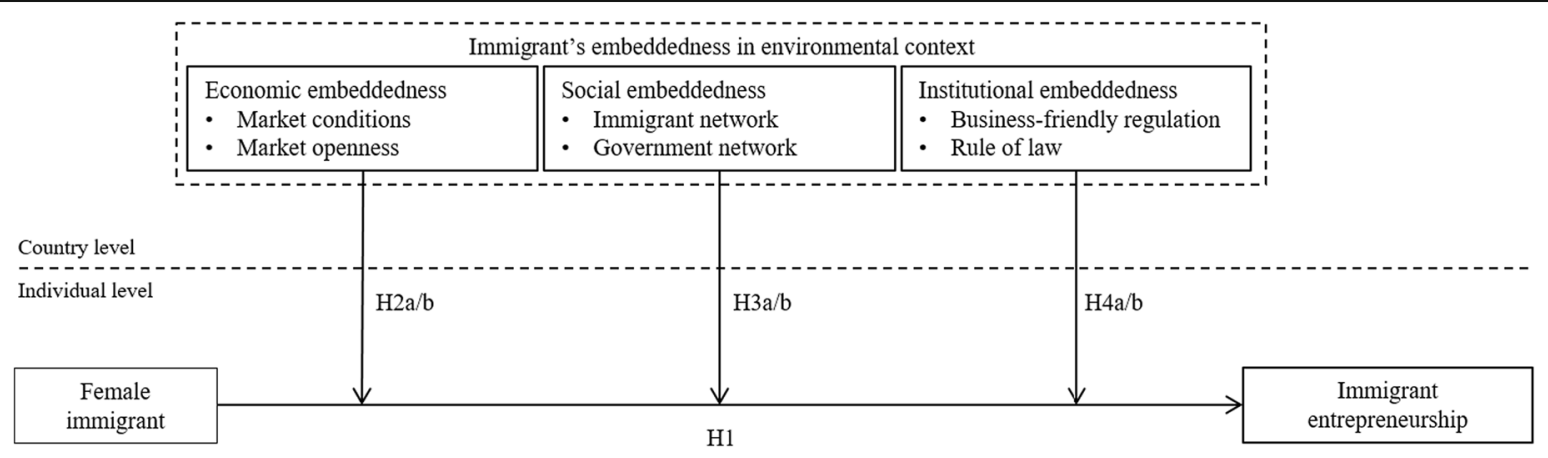

Fig. 1 Conceptual framework

We suggest that there is a similar gender gap in immigrant entrepreneurship. Several authors emphasize the disadvantages faced by female immigrants in setting up and running businesses, when compared with their male counterparts. Female immigrants usually face greater obstacles to the acquisition of start-up funding, as well as in the development of formal and informal social networks (Vaccarino et al. 2011; Azmat 2013). Furthermore, as in the case of native-born women, immigrant women probably have a negatively biased perception of their own knowledge and skills, show greater risk aversion, and may have less access to the resources required to start and run a business, which may reduce the likelihood of female immigrants to start and run a business (Terjesen et al. 2016; Wilson et al. 2007). Accordingly, we suggest that immigrant women, when compared with their male counterparts, are a priori less likely to launch and run a business, resulting in a gender gap in immigrant entrepreneurship. This means that there is a negative main effect of female gender on immigrant entrepreneurship. Consequently, we formulate our first hypothesis as follows:

Hypothesis 1 (H1): Compared with men, female immigrants are less likely to become entrepreneurs.

\subsection{The moderating role of contextual embeddedness}

Previous research presents evidence that contextual factors influence the gender gap in entrepreneurship. For instance, greater economic development is related to a larger gender gap in entrepreneurial activity (Klyver et al. 2013; van der Zwan et al. 2012; Minniti 2010; Baughn et al. 2006). There is also empirical evidence that cultural and institutional conditions affect the gender gap in entrepreneurship (Baughn et al. 2006;
Mueller 2004; Shinnar et al. 2012; Elam and Terjesen 2010; Estrin and Mickiewicz 2011; Klyver et al. 2013). Klyver et al. (2013) present empirical evidence that a higher level of country-level gender equality in the areas of economy, education, politics, and health widens the gender gap in entrepreneurship. Recently, Thébaud (2015) showed that entrepreneurship is a "Plan B" employment strategy for women if there are institutions that facilitate remaining in paid employment. Specifically, Thébaud (2015) documents that women do not need to choose self-employment as a "fallback" employment strategy if they are embedded in institutional arrangements such as paid leave, subsidized childcare, and part-time employment opportunities. Accordingly, the gender gap is greater in more developed economies with supportive institutions.

With respect to female immigrants, however, we argue that entrepreneurship is not a Plan B but rather a "Plan A" employment strategy. In many cases, immigrant women arrive in their host societies with low levels of human capital, inadequate educational qualifications and skills, and poor language proficiency. These factors negatively affect their search for traditional employment (Rath and Kloosterman 2000; Collins and Low 2010). Even when immigrant women possess strong educational backgrounds, sufficient professional qualifications, and adequate language skills, they often find that their skills, competencies, and talents are less recognized and appreciated in their host societiesthereby reducing their chances of acquiring paid employment (Levie 2007; Collins and Low 2010). As a result, entrepreneurship becomes their preferred option - the Plan A for making a living - since it allows them to use their qualifications and experiences in a practical setting to generate income. In addition, we suggest that the marginal utility of supportive environmental conditions is higher for women than for men. 
Since female immigrants show, compared with their male counterparts, typically lower levels of entrepreneurial self-efficacy and self-confidence, and have less financial and social resources, they may benefit relatively more than men from supportive contexts. Thus, favorable environmental conditions might help female immigrants to overcome the lack of confidence and resources which prevent them from setting up and running a business. Accordingly, this reduces the gender gap in immigrant entrepreneurship. In the following section, we refer to the effects of immigrants' embeddedness in supportive economic, social, and institutional environmental conditions on the gender gap in immigrant entrepreneurship to develop our specific hypotheses.

\subsubsection{The role of economic embeddedness}

The economic embeddedness of immigrants depends on the market structure, including the degree to which immigrants can find and exploit entrepreneurial opportunities (Rath and Kloosterman 2000; Kloosterman and Rath 2001). Eckhardt and Shane (2010), p. 49) define entrepreneurial opportunities as "situations in which new goods, services, raw materials, markets and organizing methods can be introduced through the formation of new means, ends, or means-ends relationships." Economies that provide more opportunities facilitate entrepreneurship in general, and also for immigrants in particular, because they are more dependent on supportive environmental conditions. Furthermore, economies need to provide easy access to markets in addition to opportunities. For instance, access to markets can be blocked by established competitors. Businesses with large resource pools can control markets and block the entry of new firms. Moreover, Aldrich and Waldinger (1990) emphasize that very strong inter-ethnic competition for jobs and business opportunities can push immigrants out of business.

We expect that an economic environment supportive of entrepreneurial activity positively affects immigrant entrepreneurship. A high level of market opportunity and market access should it make easier for immigrants to become entrepreneurially active. In addition, with regard to the structural disadvantages female immigrants face, we hypothesize that immigrant women's likelihood of starting and running a business is, compared with immigrant men's, more positively affected by a supportive economic environment. Market opportunities and barrier-free access to exploit those opportunities should mitigate the negative effects, in terms of low entrepreneurial self-efficacy, fear of failure, and lack of resources. This leads us to our next hypotheses:

Hypothesis $2 a$ (H2a): Gender gaps in immigrant entrepreneurship will be smaller in the presence of higher levels of market opportunities.

Hypothesis $2 b$ (H2b): Gender gaps in immigrant entrepreneurship will be smaller in the presence of higher levels of market access.

\subsubsection{The role of social embeddedness}

Social networks and ties have a strong influence on entrepreneurial activity (Klyver and Foley 2012; Stam et al. 2014). The mixed embeddedness approach considers this by stressing the importance of immigrants' social embeddedness in diverse social networks with both the co-ethnic community and the native community (Rath and Kloosterman 2000; Beckers and Blumberg 2013; Collins and Low 2010). Social networks can be informal (e.g., family, personal, friends, and ethnic group) and formal (e.g., business contacts, banks, lawyers, government, organizations, and associations). We focus on one informal and one formal social network: the migrant network and the government network. In previous research, both networks are discussed as critical variables influencing immigrant entrepreneurship (Bates 1997; Desiderio 2014; Kushnirovich and Heilbrunn 2008; Lassalle and McElwee 2016; Kloosterman et al. 2016).

The mixed embeddedness literature highlights the key role of vibrant immigrant enclaves for promoting immigrant entrepreneurship (Kloosterman 2003; Knight 2015; Altinay 2008; Peroni et al. 2016). Immigrant enclaves, as informal social networks, are geographic areas with a high concentration of immigrants in which immigrants generally share the same cultural identity (McEvoy and Hafeez 2009a). The similar backgrounds in an immigrant or ethnic enclave strengthen in-group solidarity among inhabitants. This in-group support facilitates immigrant entrepreneurship by providing information, assistance, and practical resources for immigrants - especially those who have just arrived in their host countries (Koelet et al. 2017; Aliaga-Isla and Rialp 2013). This informal social network helps 
immigrants overcome obstacles (e.g., a lack of financial resources) that prevent them from successfully establishing businesses and is thus an important element in the resource mobilization process (Lassalle and McElwee 2016). Furthermore, immigrant and ethnic enclaves create demand for products and services catering to the culture and taste of the immigrants' country of origin (McEvoy and Hafeez 2009b). Ethnic consumption patterns allow immigrant entrepreneurs to draw on the "traditional" knowledge, expertise, and experiences they have gained during their time in their home societies. Since ethnic enclaves continuously attract new migrants, they also offer a source of cheap labor for immigrant entrepreneurs that can facilitate entrepreneurial activity. Shinnar and Young (2008, p. 245) point out that ethnic enclaves provide entrepreneurs with "a linguistically isolated labor pool with skills that can be more efficiently tapped into by coethnic rather than majority group entrepreneurs."

Government networks (e.g., people working for government programs, agencies, science parks, and business incubators), as formal social networks provide the infrastructure which helps potential immigrant entrepreneurs to recognize and exploit opportunities (Desiderio 2014; Marchand and Siegel 2014). Government network support facilitates the mobilization of resources, and help immigrants to pursue entrepreneurial opportunities (Heilbrunn and Kushnirovich 2008). For instance, government-supported entrepreneurship programs provide relevant knowledge and skills that facilitate new business formation and thus help spur entrepreneurial activities. They often include educational modules on topics such as marketing, identifying business opportunities, networking, accounting, business planning, and financial management. In addition, governments in host countries sometimes launch special government programs specifically designed to help aspiring immigrant entrepreneurs improve their language proficiency, business skills, creditworthiness, and understanding of legal and regulatory issues (Desiderio 2014).

We argue that immigrant women depend more on both informal and formal network support than men. Male immigrants, compared with female immigrants, have stronger informal and formal social ties and thus more opportunities to acquire both financial resources and general assistance in starting and running a business (Marchand and Siegel 2014). Marchand and Siegel (2014) explain that immigrant men's larger networks result from their stronger presence in the public domain.
While female immigrants are more involved in the private domain and tend to set up more home-based businesses, male immigrants interact more in public outside of the home, which allows them to more easily and efficiently build up varied kinds of supportive social networks. In addition, immigrant men live, on average, for a longer period of time in their host countries than immigrant women, a fact which facilitates the development of networks and familiarization with the structures of the host country (Marchand and Siegel 2014). Since female immigrants cannot as easily obtain resources from narrow and extended networks, we hypothesize that female immigrants would benefit more, compared with male immigrants, from strong immigrant and government network support. If informal and formal networks provide material resources and services, and provide emotional support and encouragement to female immigrants, this should evoke a positive impact on female immigrants' entrepreneurial self-efficacy and self-confidence regarding the success of one's venture, and thus strengthen their belief that entrepreneurship is feasible, desirable, and financially lucrative. For this reason, we propose that an overall higher level of support provided by immigrant and government networks influences the proposed gender gap in immigrant entrepreneurship. Thus, our next hypotheses are as follows:

Hypothesis $3 a$ (H3a): Gender gaps in immigrant entrepreneurship will be smaller in the presence of higher levels of migration network support.

Hypothesis $3 b$ (H3b): Gender gaps in immigrant entrepreneurship will be smaller in the presence of higher levels of government network support.

\subsubsection{The role of institutional embeddedness}

Immigrants are embedded in institutional structures which either enhance or limit the attractiveness of entrepreneurship (Rath and Kloosterman 2000; McEvoy and Hafeez 2009b). Research underscores the critical role of laws, rules, and regulations-so-called formal institutions-for entrepreneurship (Acs et al. 2008; Begley et al. 2005; Belitski et al. 2016; Chowdhury et al. 2015). We focus on two institutions that have been shown to be important requirements of entrepreneurship: business-friendly regulation and the rule of law (e.g., Djankov et al. 2002; Chowdhury et al. 2015; McMullen et al. 2008; Estrin et al. 2013). 
Business-friendly regulation encourages entrepreneurial activity. Reducing market entry barriers-such as licensing and permitting fees, complex compliance procedures, and the overall time it takes to open a business - has been shown to support entrepreneurship (Djankov et al. 2002; Lassmann and Busch 2015). In addition, business-friendly tax policy is an essential institutional factor that influences how aspiring entrepreneurs perceive their expected returns (McMullen et al. 2008). Previous research found evidence that entrepreneurial activity is negatively linked to higher taxes (Estrin et al. 2013; Djankov et al. 2010; Baliamoune-Lutz and Garello 2014). Similarly, complex government bureaucracy, regulations, and licensing requirements can harm new firm activities (Chowdhury et al. 2015).

The rule of law captures the quality of due process in law, the quality of contract enforcement and property rights, and the degree of corruption control. Research highlights the importance of strong property protection, law enforcement, and the absence of corruption not only for entrepreneurial activity, but also for the general functioning of a market system, including investments, innovations, and economic growth (McMullen et al. 2008; Acemoglu et al. 2005; Bowen and de Clercq 2008). Several authors present empirical evidence for a positive relationship between rule of law and entrepreneurial activity (Estrin et al. 2013; Chowdhury et al. 2015; McMullen et al. 2008; Estrin and Mickiewicz 2011), showing that entrepreneurs, as significant creators of innovation, need a guarantee of return on their investments in their innovations (McMullen et al. 2008; Estrin et al. 2013). High-quality property regulation and law enforcement decreases the risk associated with efforts in innovative entrepreneurial activities. These standards protect against expropriation and encourage aspiring entrepreneurs to accumulate income, make investments and long-term plans, and become more specialized (McMullen et al. 2008; Autio and Acs 2010).

We expect that higher levels of business-friendly regulation and stronger adherence to the rule of law are likely to encourage entrepreneurial activity among both male and female immigrants. However, in line with our argument, we hypothesize that female immigrants would benefit more strongly from better business regulation and stronger adherence to the rule of law. A welldefined business regulation framework and trust in the government's willingness to protect property rights guarantees lower costs in the start-up process, a higher level of property security, and easier access to financial resources. Embeddedness in well-functioning institutional settings should positively affect female immigrants' individual sense of control over a situation and its outcomes (Estrin and Mickiewicz 2011). This should, in turn, positively influence female immigrants' risk perception and beliefs about their ability to successfully start and run businesses. In contrast, a low-quality business regulatory framework, costly regulations and guidelines, administrative burdens, corruption, and weaker property rights hamper both the prevalence of opportunities and the resources available to exploit those opportunities, which should preserve women's disadvantaged position with respect to social and financial resources. Against this background, we hypothesize that higher-quality business regulation and strong rule of law weaken the proposed negative relationship between female gender and immigrant entrepreneurship, resulting in a smaller gender gap in immigrant entrepreneurship. Thus, our final hypotheses are formulated as follows:

Hypothesis 4a (H4a): Gender gaps in immigrant entrepreneurship will be smaller in the presence of higher levels business-friendly regulations.

Hypothesis $4 b$ (H4b): Gender gaps in immigrant entrepreneurship will be smaller in the presence of higher levels of rule of law.

\section{Data and methods}

\subsection{Data collection}

We obtained individual and country-level data from multiple sources. First, we used the individual-level data of immigrants from the Global Entrepreneurship Monitor's (GEM) Adult Population Survey (APS) 2012 database. GEM's APS provides standardized data on each population's entrepreneurial preferences, capacities, and activities (Sternberg and Wennekers 2005). The survey is administrated to a representative sample of adults in many countries, making it the most suitable data-driven study of entrepreneurial activity worldwide (Langowitz and Minniti 2007; Urbano and Alvarez 2014). In 2012, GEM added questions to its survey on the subject of immigrant entrepreneurship, allowing the differentiation of individuals according to their country of origin. 
Second, we incorporate country-level data from several sources to assess a country's economic, social, and institutional environment (in which immigrants are embedded). We used GEM's National Experts' Survey (NES) 2012 database, which provides background information from selected experts in each country on factors that influence entrepreneurial activity in their respective countries (Xavier et al. 2012). GEM's NES employs standardized questions and validated measurement scales (De Clercq et al. 2013), developed to overcome the lack of national-harmonized indices or measures that could be used for comparative studies (Amorós and Bosma 2014). GEM's NES database is widely recognized and has been frequently used in recent entrepreneurship studies (De Clercq et al. 2013; Levie and Autio 2008; Bowen and de Clercq 2008; Martínez-Fierro et al. 2016). In addition, we obtained data from the World Bank database.

\subsection{Measures}

Immigrant entrepreneurship We used the total earlystage entrepreneurial activity (TEA) of immigrants as the dependent variable. Immigrant entrepreneurship is coded 1 if the immigrant is in the process of starting a business or is currently the owner of a young business that is not older than 3.5 years (Urbano and Alvarez 2014) and 0 in the other case.

Gender Gender is the independent variable at individual level. It is a binary variable coded as 1 if the immigrant is female and 0 if the immigrant is male.

Market opportunities Market opportunities measure the existence of opportunities for entrepreneurship in an economy. The index is based on the average score (5point scale ${ }^{1}$ ) per country on five statements from the GEM's NES database: (1) there are plenty of good opportunities for the creation of new firms, (2) there are more good opportunities for the creation of new firms than there are people able to take advantage of them, (3) good opportunities for new firms have considerably increased in the past 5 years, (4) individuals can easily pursue entrepreneurial opportunities, and (5) there

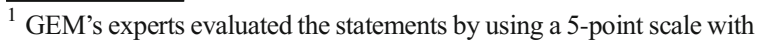
1 representing "Completely False" response, 2 representing "Somewhat False" response, 3 representing "Neither True nor False" response, 4 representing "Somewhat True" response, and 5 representing "Completely True" response (Xavier et al. 2012).
}

are plenty of good opportunities to create truly high growth firms. The Cronbach's alpha for this index was 0.872 .

Market access Market access measures the extent to which new and growing firms can enter new markets without any problems. The index is based on the average score (5-point scale) per country on three statements from the GEM's NES database: (1) new and growing firms can easily enter new markets, (2) new and growing firms can afford the cost of market entry, and (3) new and growing firms can enter markets without being unfairly blocked by established firms. The Cronbach's alpha for this index was 0.916 .

Migrant network We take into account the international foreign-born migrant stock of a country, measured as percentage of people (including refugees) born in a country other than the host country. We use this as a proxy for measuring the migrant network due to missing alternatives. Data are taken from the World Bank's 2010 database.

Government network Government network measures the presence and quality of government support programs provided for early-stage entrepreneurs. The index is based on the average score (five-point scale) per country on six statements from the GEM's NES database: (1) a wide range of government assistance for new and growing firms can be obtained through contact with a single agency, (2) science parks and business incubators provide effective support for new and growing firms, (3) there are an adequate number of government programs for new and growing businesses, (4) the people working for government agencies are competent and effective in supporting new and growing firms, (5) almost anyone who needs help from a government program for a new or growing business can find what they need, and (6) government programs aimed at supporting new and growing firms are effective. The Cronbach's alpha for this index was 0.955 .

Business-friendly regulation Business-friendly regulation is measured by the World Bank's Ease of Doing Business distance to frontier score, which captures the gap between a country's performance and a measure of best practice across the entire sample of 41 indicators for 10 business-friendly regulation areas including: (1) starting a business, (2) dealing with construction 
permits, (3) getting electricity, (4) registering property, (5) getting credit, (6) protecting minority investors, (7) paying taxes, (8) trading across borders, (9) enforcing contracts, and (10) resolving insolvency. Data are taken from the World Bank's 2012 database.

Rule of law Rule of law is measured by the World Bank's rule of law index, which captures perceptions about the extent to which agents have confidence in and abide by the rules of society, with particular focus on the quality of contract enforcement, property rights, the police and the courts, as well as the likelihood of crime and violence (Kaufmann et al. 2011). Data are taken from the World Bank's 2012 database.

In accordance with prior research (Klyver et al. 2013; De Clercq et al. 2013; Thébaud 2015; Hörisch et al. 2017), we controlled for a number of variables. At the individual level, we controlled for age, household size, household income, education, start-up skills, fear of failure, know an entrepreneur, employment status, and whether or not the individual is a first-generation immigrant.

Age The relevance of age has been discussed in a number of studies (Kautonen et al. 2014; Minola et al. 2016; Funken and Gielnik 2015). We measured age by the immigrant's exact age as a continuous variable.

Household income Household income reflects the individual's potential available financial resources and is an important factor for entrepreneurship (Evans and Jovanovic 1989). Household income is an important resource for immigrants, allowing them to invest in a business and to survive for a period of time without revenues (as is often the case during the start-up phase). The immigrants were asked to provide information about their household income, and were divided into three categories (lower 33\%; middle 33\%; upper 33\%) based on the income distribution of their host country.

Education Many authors agree that education is positively related to entrepreneurial activity (Bowen and de Clercq 2008; Unger et al. 2011). This positive correlation holds for immigrants (Shinnar and Young 2008; Borjas 1986). Education is taken into account by a categorical variable which consists of five groups: 0 for none, 1 for some secondary, 2 for secondary degree, 3 for post-secondary, and 4 for graduate experience education. The entrepreneurs were asked to identify the highest degree they had earned.

Start-up skills Several authors discuss the key role of (perceived) start-up skills on an individual's willingness to start and run a business (Wilson et al. 2009; Chen et al. 1998; Wilson et al. 2007; Rauch and Frese 2007). To consider start-up skills, we used an established dummy variable from the GEM's APS database (Stephan and Uhlaner 2010; Koellinger et al. 2013; Noguera et al. 2013). The binary variable is coded as 1 if the immigrant affirmed the following statement: "Do you have the knowledge, skill and experience required to start a new business?"

Fear of failure Fear of failure is related to an individual's degree of risk aversion towards entrepreneurial activity (Caliendo et al. 2009). Several studies provide empirical evidence of a strong negative and significant correlation between fear of failure and the likelihood of initiating and running a business (Wennberg et al. 2013; Arenius and Minniti 2005). With regard to entrepreneurship, several authors have discussed the fact that women show, compared with men, stronger fear of failure (e.g., Wagner 2007). We measured fear of failure with a frequently used dummy variable (Minniti 2010; Bosma and Levie 2009; Wagner 2007; Koellinger et al. 2013), coded as 1 if the immigrant answered "yes" to the following statement: "Would fear of failure prevent you from starting a business?"

Know an entrepreneur Individuals who know an entrepreneur are more likely to start and run a business (Arenius and Minniti 2005). Know an entrepreneur is a frequently used dummy variable (Arenius and Minniti 2005; Koellinger et al. 2013; Noguera et al. 2013), taking the value 1 if the immigrant answered "yes" to the following statement: "Do you know someone personally who started a business in the past 2 years?"

Employment status Empirical evidence shows that the likelihood of becoming entrepreneurially active is significantly higher for individuals who are employed in a full- or part-time wage job (Klyver et al. 2013). Since women's participation in the labor market is more frequently interrupted than men's, significant differences exist in employment status across gender (Kelley et al. 2013). Employment status is coded as 1 if the immigrant works full or part time, and 0 if not. 
First-generation immigrant First-generation immigrant is coded as 1 if the immigrant was not born in the host country, and as 0 if the immigrant was born in the host country but not one or both parents (second-generation immigrant).

At the country level, we controlled for GDP per capita, GDP growth, and unemployment, which have been frequently used as country-level controls in previous research (Thébaud 2015; Wennberg et al. 2013).

GDP per capita This is the gross domestic product divided by midyear population measured in constant 2010 US dollars.

GDP growth per capita This is the annual percentage growth rate of GDP per capita based on constant local currency. Aggregates are based on constant 2010 US dollars.

Unemployment This refers to the portion of the labor force that is without work but available for and seeking employment.

Table 1 displays the means, standard deviations, maximum, and minimum of the variables.

\subsection{Data analysis}

To test our hypotheses, we conducted multilevel mixedeffects logistic regression using the "melogit" command in Stata 15. Multilevel modeling is superior to traditional regression techniques because the latter provide inefficient estimates and biased standard errors in the presence of nested data (Snijders and Bosker 2012; De Clercq et al. 2013; Mikucka 2014). In our data set, individuals were nested in countries. Ignoring the interdependency between individual and country-level data may thus lead to artificial significant effects (Snijders and Bosker 2012). To avoid inefficient estimation and biased standard errors, multilevel modeling considers the nested data structure and simultaneously estimates the variability in the dependent variable within and between countries (Snijders and Bosker 2012; Mikucka 2014). Compared with conventional models, the multilevel mixed-effects approach accounts for fixed and random effects to adequately model effects between variables on the different levels of the research design (Snijders and Bosker 2012).

Since we selected only those countries for which all individual and country-level variables considered in this analysis were available, the number of observations was low in some countries. For this reason, we followed the rule proposed for multilevel models and included only countries having at least 30 units at each level of the analysis (e.g., Maas and Hox 2004). Our final sample is comprised of 11,471 immigrants located in 51 countries.

\section{Results}

\subsection{Main results}

Table 2 provides the correlation matrix. The correlation matrix reveals that immigrant entrepreneurship is negatively linked to gender. Further, we find positive, significant bivariate relationships between immigrant entrepreneurship and education, household income, employment status, start-up skills, know an entrepreneur, household size, and negative and significant bivariate relationships with age and fear of failure.

Table 3 presents the empirical results of our multilevel mixed effects logistic regressions. Before analyzing our models with predictors, we estimated a null model (or intercept only model) for immigrant entrepreneurship. We computed the intraclass correlation coefficient (ICC) which estimates the percentage of total variance in immigrant entrepreneurship that exists between countries. The ICC is calculated directly by dividing the between countries variance by the total variance, and is interpreted as the proportion of total residual variation that is due to differences between countries. We found that about $13.2 \%$ of the immigrant entrepreneurship variance occurs between countries. In international business research, intraclass correlation coefficients of $0.05,0.10$, and 0.15 are considered small, medium, and large, respectively (Hox 2010). Thus, multilevel specification is reasonable.

Model 1 includes the control variables, and Model 2 adds gender, the independent variable. Models 3 and 4 include the interactions terms between gender and the economic embeddedness variables. Models 5 and 6 integrate the interaction terms between gender and the social embeddedness variables, and Models 7 and 8 include the interaction terms between gender and the institutional embeddedness variables.

The results of Model 1 show that the control variables age $(\beta=-0.018 ; p<0.01)$, employment status $(\beta=1.059 ; p<0.01)$, start-up skills $(\beta=1.501$; $p<0.01)$, fear of failure $(\beta=-0.558 ; p<0.01)$, know 
Table 1 Descriptive statistics

\begin{tabular}{|c|c|c|c|c|c|}
\hline Variable & Number & Mean & SD & Min & Max \\
\hline Immigrant entrepreneurship & 11,471 & 0.112 & 0.315 & 0 & 1 \\
\hline Gender & 11,471 & 0.521 & 0.500 & 0 & 1 \\
\hline Age & 11,471 & 40.681 & 12.615 & 18 & 64 \\
\hline Education & 11,471 & 2.244 & 1.030 & 0 & 4 \\
\hline Household income & 11,471 & 1.046 & 0.814 & 0 & 2 \\
\hline Employment status & 11,471 & 0.719 & 0.449 & 0 & 1 \\
\hline Start-up skills & 11,471 & 0.467 & 0.499 & 0 & 1 \\
\hline Fear of failure & 11,471 & 0.446 & 0.497 & 0 & 1 \\
\hline Know an entrepreneur & 11,471 & 0.339 & 0.473 & 0 & 1 \\
\hline Household size & 11,471 & 3.281 & 1.309 & 1 & 5 \\
\hline First-generation immigrant & 11,471 & 0.500 & 0.500 & 0 & 1 \\
\hline GDP per capita & 51 & $23,167.270$ & $20,740.600$ & 461.887 & $88,585.360$ \\
\hline GDP growth per capita & 51 & 0.920 & 2.755 & -6.798 & 7.344 \\
\hline Unemployment & 51 & 10.342 & 6.919 & 0.580 & 31 \\
\hline Market opportunities & 51 & 3.287 & 0.385 & 2.122 & 3.978 \\
\hline Market access & 51 & 2.614 & 0.322 & 2.073 & 3.543 \\
\hline Immigrant network & 51 & 8.691 & 7.872 & 0.271 & 42.623 \\
\hline Government network & 51 & 2.687 & 0.455 & 1.713 & 3.570 \\
\hline Business-friendly regulation & 51 & 68.241 & 11.213 & 40.450 & 90.410 \\
\hline Rule of law & 51 & 67.965 & 23.807 & 7.512 & 100 \\
\hline
\end{tabular}

an entrepreneur $(\beta=0.891 ; p<0.01)$, and country-level unemployment $(\beta=-0.030 ; p<0.05)$ are significantly associated with immigrant entrepreneurship.

The results of Model 2 reveal that a gender gap exists in immigrant entrepreneurship $(\beta=-0.246 ; p<0.01)$. The negative coefficient indicates that female immigrants, compared with their male counterparts, are less likely to engage in entrepreneurship. This pattern is stable. Across all models, a negative relationship between gender and immigrant entrepreneurship was found, indicating that female immigrants are less likely to engage in entrepreneurship. Thus, we confirm Hypothesis 1 .

We expected that the gender gap in immigrant entrepreneurship is smaller in countries with supportive environmental conditions. First, we examined the role of immigrants' economic embeddedness. The results of Models 3 and 4 shown in Table 3 show positive moderating effects of market opportunities $(\beta=0.507 ; p<0.01)$ and market access $(\beta=0.457 ; p<0.05)$ on the relationship between gender and immigrant entrepreneurship. This implies that the existence and accessibility of opportunities affects female immigrants more positively. Thus, we confirm Hypotheses $2 \mathrm{a}$ and $2 \mathrm{~b}$.

Next, we examined the specific effects of immigrant and government networks on the association between gender and immigrant entrepreneurship. The results of Models 5 and 6 provide support for our Hypotheses $3 \mathrm{a}$ and $3 \mathrm{~b}$. Immigrant network $(\beta=0.015 ; p<0.05)$ and government network $(\beta=0.442 ; p<0.01)$ increase the likelihood of female immigrants choosing entrepreneurial activity, compared with male immigrants, thereby reducing the gender gap in immigrant entrepreneurship.

The institutional embeddedness models estimated the moderating effect of business-friendly regulation and rule of law on the relationship between gender and immigrant entrepreneurship. The results of Models 7 and 8 indicate that business-friendly regulation $(\beta=$ $0.014 ; p<0.05)$ and rule of law $(\beta=0.008 ; p<0.01)$ positively moderate the gender-immigrant entrepreneurship relation. The gender gap in immigrant entrepreneurship is smaller in countries with better businessfriendly regulation and stronger adherence to the rule of law. Thus, Hypotheses $4 \mathrm{a}$ and $4 \mathrm{~b}$ are confirmed. 


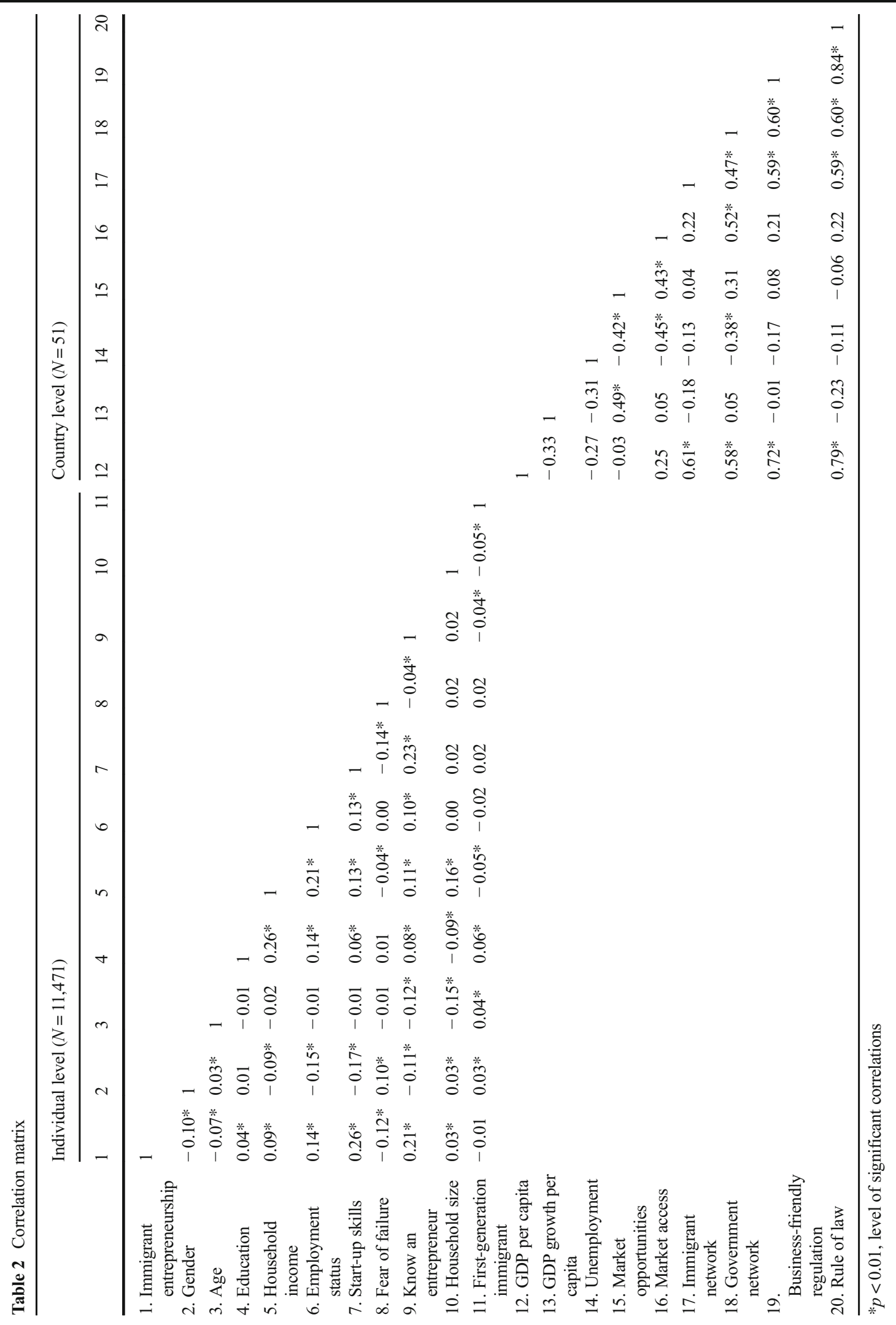




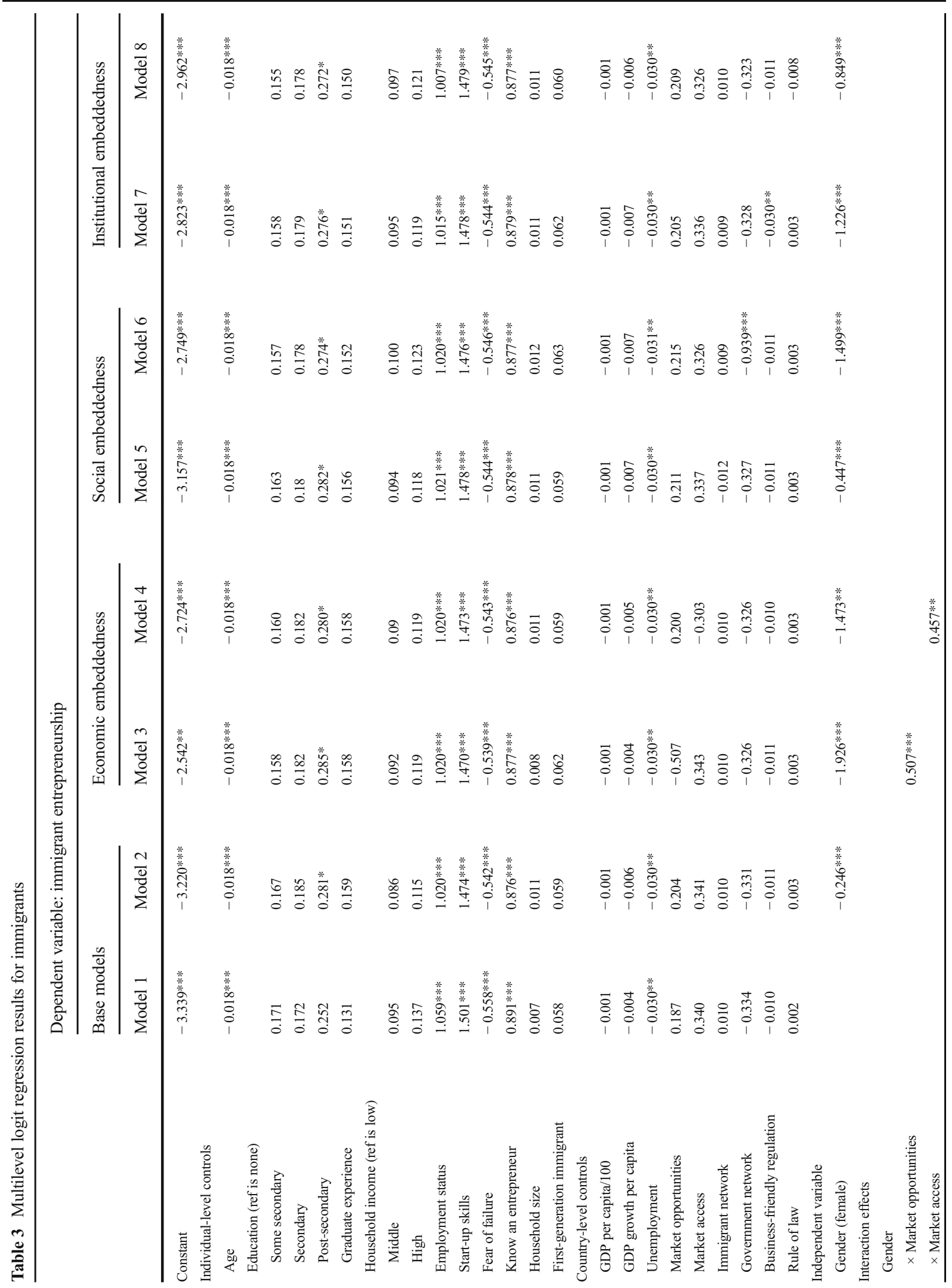




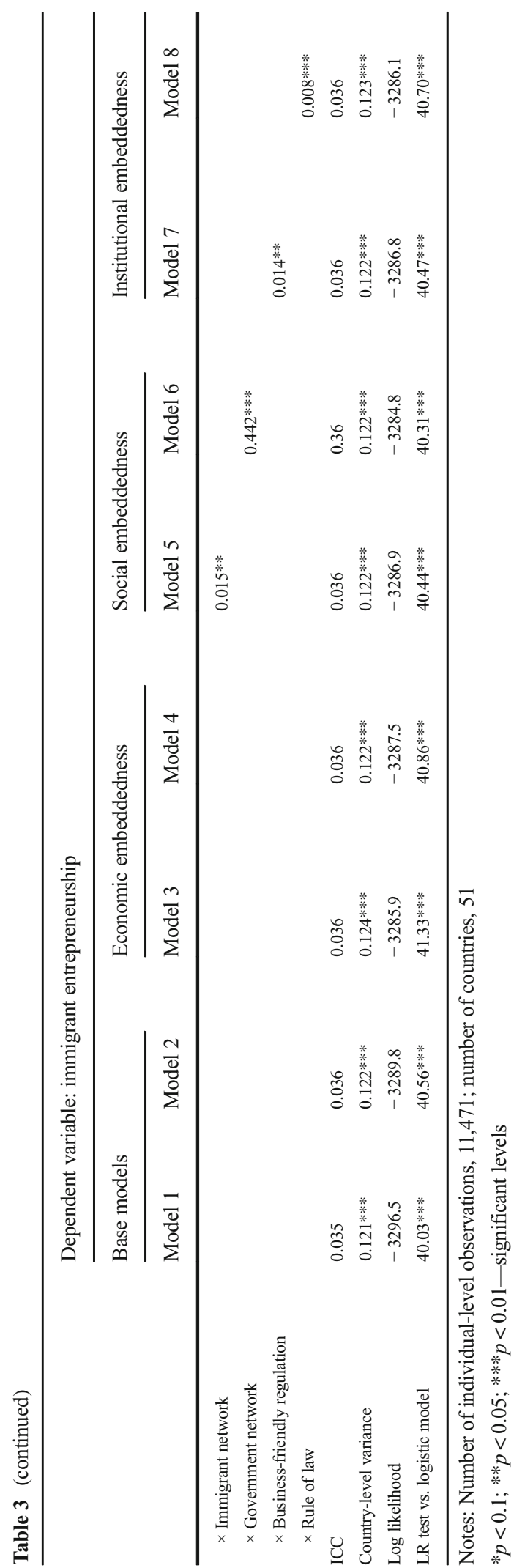

\subsection{Post hoc results 1: forced immigrants}

We also explored whether our findings are robust for forced immigrants. Forced immigrants, who are displaced by violence and conflicts, environmental disasters, or development-induced re-settlement, tend to arrive in their host countries with very limited resources - a fact which makes them relatively more dependent on the host country's support. Consequently, the relationships that we found for immigrants should also hold for forced immigrants. To analyze the gender gap in forced immigrant entrepreneurship, we considered data of only those immigrants who migrated from fragile states, which typically fail to perform basic functions in the areas of governance, security, education, economic development, and human rights. To define immigrants as forced immigrants, we draw on Fragile States Index data from the Fund for Peace Website. The Fragile States Index assesses the vulnerability of states to collapse based on 12 key political, social and economic indicators and over 100 sub-indicators (Carlsen and Bruggemann 2017). The Fragile States Index sorts countries into four categories, with respect to the country's fragility and vulnerability: sustainable, stable, warning, and alert. We defined immigrants of the first and second generation as forced immigrants when they (or their parents) migrated from countries ranked as either "warning" (Fragile States Index, 60.0-89.9) or "alert" (Fragile States Index, 90.0-120.0). The results shown in Table 4 reveal that a gender gap in entrepreneurship exists among forced immigrants. In addition, the moderating effects are consistent with those shown in Table 3. Supportive economic, social, and institutional conditions mitigate the negative relationship between forced female immigrant and entrepreneurial activity, thereby narrowing the gender gap in forced immigrant entrepreneurship. A noteworthy observation was that the coefficients of the moderating effects were slightly stronger compared with those shown in Table 3, possibly providing first evidence that the effect of a supportive host country's environment is even more important for forced female immigrants.

\subsection{Post hoc results 2: natives}

One may assume that the positive moderating effect of the economic, social, and institutional environment on the association between gender and entrepreneurship applies to both native-born and immigrant individuals, 


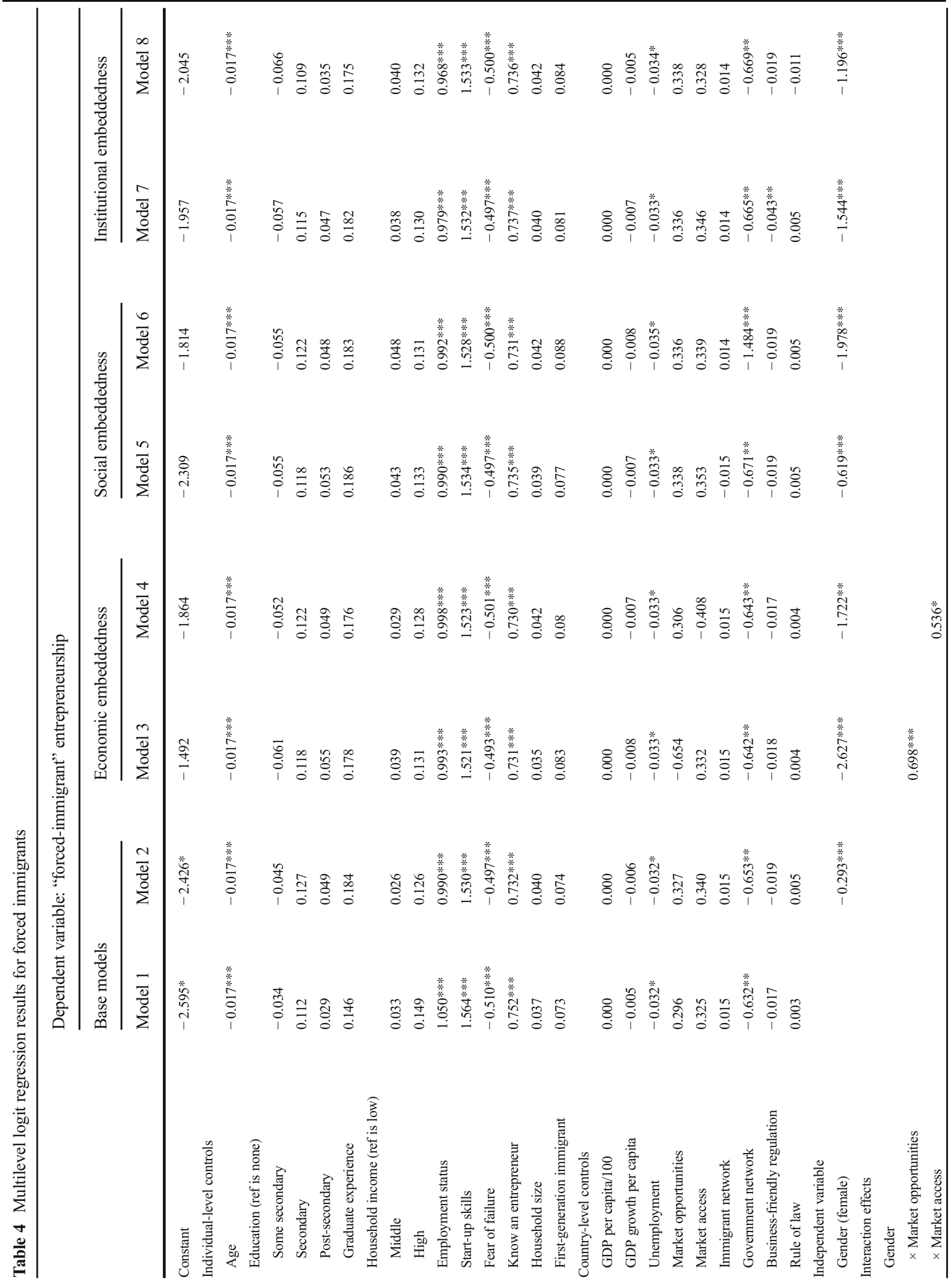


implying that our results only mirror a general pattern in the relationship between male and female entrepreneurship. However, we argued earlier that entrepreneurship is a Plan A employment strategy for female immigrants as a result of missing alternatives, whereas it is a Plan B employment strategy for female natives who have a higher level of freedom with regard to job choices. Without differentiating between native-born and immigrant individuals, Thébaud (2015) and Klyver et al. (2013) present general evidence that supportive environmental conditions negatively affect women's selfemployment choice compared with that of men, thereby widening the gender gap in entrepreneurship. According to these findings, entrepreneurship is not the first choice for women when the environmental conditions are better for them. To explore the differences between immigrants and natives concerning the gender gap in entrepreneurship, we conducted the same analysis introduced above for native-born individuals. The results are presented in Table 5. In line with our reasoning, we found significant negative interactions between gender and the contextual factors in five of six moderating models, indicating that good environmental conditions influence the self-employment choices of immigrant and native women differently. In contrast with immigrant women, the gender gap is widened for native women in a supportive environment. Thus, a supportive environment has contrary effects for immigrant and native women regarding their likelihood of engaging in entrepreneurship.

\section{Discussion and conclusion}

\subsection{Discussion}

The purpose of this study was to investigate the gender gap in immigrant entrepreneurship - an area that is still largely unexplored. To provide a better understanding of the gender gap in immigrant entrepreneurship, we draw on the mixed embeddedness approach, which emphasizes the central role of the host country's economic, social, and institutional environment for immigrant entrepreneurship (Kloosterman et al. 1999; Rath and Kloosterman 2000; Kloosterman and Rath 2001; Kloosterman 2003). Previous research documents the important role of supportive and barrier-free contexts for people's likelihood of starting and running a business 


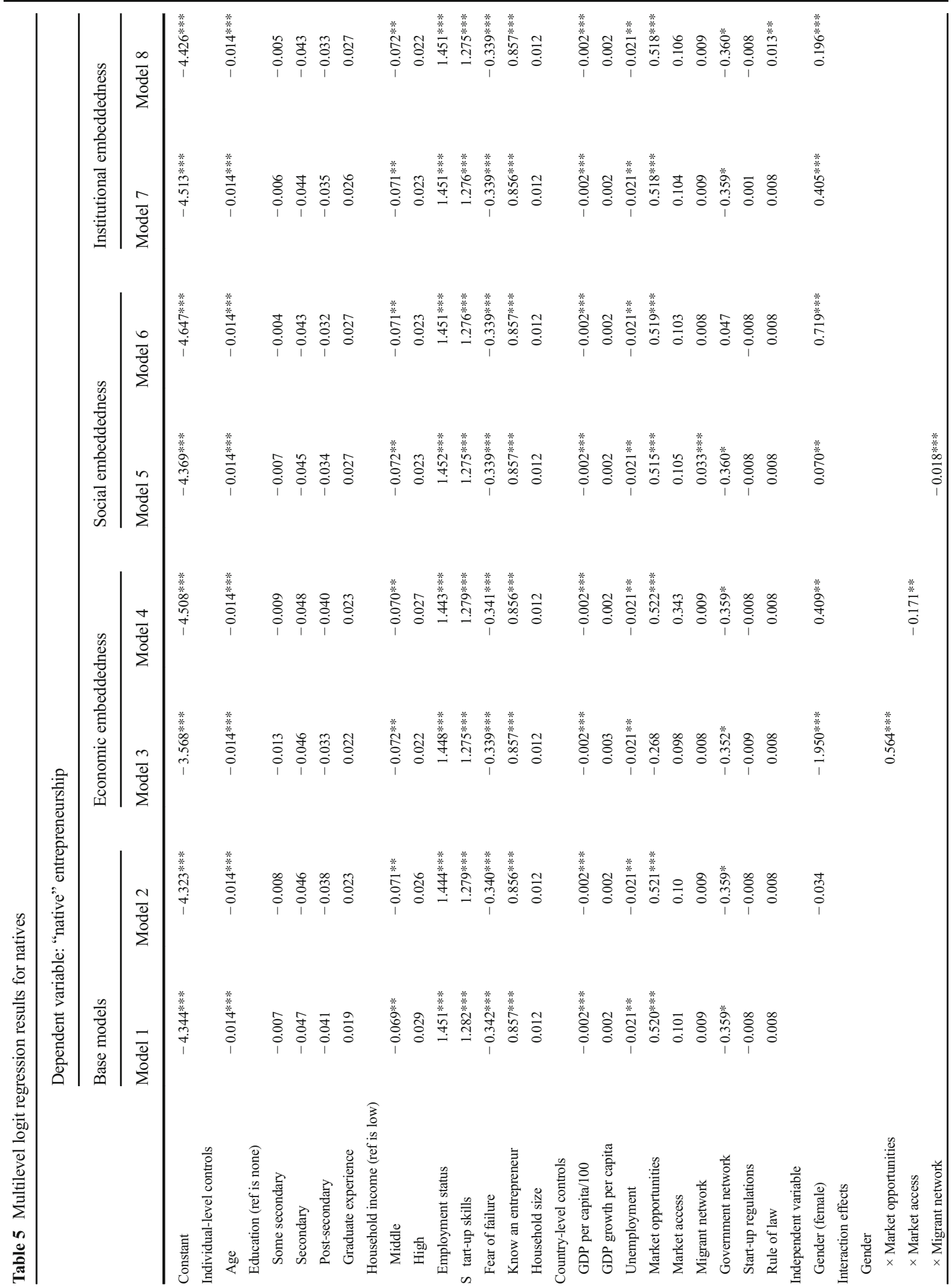


(Lüthje and Franke 2003; Pruett et al. 2009; Welter and Smallbone 2011). Accordingly, we argue that context plays an important role in immigrant entrepreneurship. Specifically, we suggest that immigrant women benefit more strongly from a supportive environment than men because women are generally in a more disadvantaged position for entrepreneurship. Previous research documents that female immigrants face greater problems when it comes to start-up financing, the development of formal and informal social networks, and economic rights (e.g., Vaccarino et al. 2011; Azmat 2013), which contributes to their relatively lower entrepreneurial activity. This disadvantaged position should thus result in a stronger need for supportive environmental conditions among immigrant women. If the environment responds to this stronger need of immigrant women, it should affect immigrant women's readiness to start and run a business relatively more than men's readiness, as men generally have better access to varied resources and are thus less dependent on environmental conditions that facilitate entrepreneurship.

We tested our hypotheses with data of 11,471 immigrants from 51 countries. Our findings reveal that female immigrants, compared with their male counterparts, are less likely to start and run a business. This result supports the findings of previous literature, which have not been specifically related to immigrants, but have shown that women are less likely to be entrepreneurs than men across countries and cultures (Minniti and Nardone 2007; Koellinger et al. 2013; Klyver et al. 2013; Thébaud 2015). Moreover, we found empirical evidence that the relationship between gender and immigrant entrepreneurship is affected by immigrants' embeddedness in a supportive economic, social, and institutional environment. The gender gap in immigrant entrepreneurship becomes smaller when the host society provides a supportive environment for entrepreneurship. Our findings indicate that immigrant men, in contrast with female immigrants, are less dependent on contextual factors. Thus, our results reveal that the marginal utility of a supportive context is higher for women than for men. We assume that a supportive national environment shows a relatively stronger positive effect on a female immigrant's entrepreneurial self-efficacy or self-confidence in one's own talents, skills, and capabilities. By employing two post hoc analyses, we show that the positive moderating impact of favorable 
environmental conditions can be replicated for forced immigrants but not for native-born individuals.

\subsection{Contribution}

This study contributes to the current discourse in immigrant and female entrepreneurship in several ways. First, this study provides new insight concerning gendered patterns in immigrant entrepreneurship from a multicountry perspective. Drawing on a mixed embeddedness perspective that includes an interactionist approach (Frese and Gielnik 2014; Welter 2010), we discuss and show that a favorable environmental context narrows the gender gap in immigrant entrepreneurship. In addition, we show that the moderating effects are robust for forced immigrants who migrated from fragile states. The finding that only the interactions terms (and not the embeddedness variables) are positively and significantly related to immigrant entrepreneurship provides support for an interactionist perspective that individual and contextual factors jointly influence entrepreneurship (Frese and Gielnik 2014; Welter 2010). This means that an interactionist perspective building on the mixed embeddedness approach helps to better understand the gender gap in immigrant entrepreneurship.

Second, we present new evidence that favorable environmental conditions impact immigrant and native-born individuals differently. Whereas favorable environmental conditions mitigate the negative relationship between immigrant women and entrepreneurship, they amplify the gender gap in entrepreneurship among native-born individuals. Therefore, we argue that entrepreneurship is a Plan A employment strategy for female immigrants, whereas it is merely a Plan B employment strategy for native-born women. While recent research argues that institutional support for women may disintegrate women's self-employment choice (Klyver et al. 2013; Thébaud 2015), this study's results show that this does not always have to be the case. In contrast with native women, immigrant women benefit from institutional support. Thus, we contribute to the female entrepreneurship literature by providing new insight into how the same environmental conditions affect the gender gap in entrepreneurship differently.

These gender differences in immigrant entrepreneurship decisions offer valuable insights for designing policy measures aimed at fostering female immigrant entrepreneurship. Previous research highlights the positive impact immigrant entrepreneurs can affect for their host societies. By creating jobs, and by contributing to economic growth and innovation (Baycan-Levent and Nijkamp 2009; Marchand and Siegel 2014; Saxenian 2002), immigrant entrepreneurs can help to balance economic development, quality of life, and social cohesion (cf. Levie 2007). Accordingly, policies aimed at economically integrating both immigrant men and women through entrepreneurial activity can foster the welfare of social units, such as families, communities, and societies. Policies to strengthen immigrant entrepreneurship can include various dimensions, ranging from active financial and educational support to formal rules and regulations that guarantee entrepreneurs barrier-free access to markets, low corruption, and strong law enforcement. For instance, business support programs, which are typically provided by national governments and implemented at the local and regional levels, can positively impact financial resources, social networks, and human capital among (potential) immigrant entrepreneurs, thereby facilitating self-employment (Desiderio 2014). Entrepreneurship training, support in administrative issues important for business activity, legal advice on laws and regulations, mentoring, and start-up funding support can be a significant catalyst for entrepreneurial activity among immigrants (Desiderio 2014). Also, structural policies aimed at providing a business-friendly environment - which may include lower taxes for start-ups, labor market flexibility, strong law enforcement laws, and anti-corruption legislation - could positively affect immigrant entrepreneurship, particularly among women as our results show.

\subsection{Limitations and avenues for future research}

Despite the value of our findings, our research inevitably has some limitations. Our analysis is cross-sectional and we thus do not follow individuals over time. We must therefore speak of relationships, and can only speculate as to whether causal mechanisms work behind the relationship we identify. Future research could focus on variations in immigrant entrepreneurship over time as a consequence of changes in environmental conditions; this would offer a better understanding of causes and consequences in immigrant entrepreneurship. Moreover, three of our mixed embeddedness components are based on impressions and judgments of experts, rather than on hard data (Levie and Autio 2008). Since hard data on entrepreneurship issues are not always available for a high number of countries, we 
assessed GEM's National Experts' Survey ratings as the best alternative for our purpose. Future research could consider further contextual variables based on hard data, such as immigrant discrimination (xenophobia, acceptance of certain religious groups), legal issues (fiscal freedom, labor laws, or the economic, political, and social rights of immigrants), social security systems (including child-care), and taxation (e.g., tax treatment of double income) which may explain differences in immigrant entrepreneurship in general and entrepreneurial gender imbalances across countries in particular (van der Zwan et al. 2012; Baycan-Levent and Nijkamp 2009). An interesting further line of research could examine the role of home country-specific factors in immigrant entrepreneurship. An analysis of the home country's cultural characteristics (social trust, self-expression/emancipative values, uncertainty avoidance, power distance, and entrepreneurial culture) might be helpful for gaining a deeper insight into immigrants' entrepreneurial attitudes and behavior, gender differences in immigrant entrepreneurial activity, as well as further significant variations between different immigrant groups (Azmat 2013; Basu and Altinay 2002; Clark and Drinkwater 2010; Hechavarría and Reynolds 2009; De Clercq et al. 2013).

The findings of this study must be qualified by the limitations just described. Nonetheless, our results provide first valuable insights into how environmental conditions influence the gender gap in (forced) immigrant entrepreneurship. We hope this study will be a starting point for further (multi-country) research in (female) immigrant entrepreneurship.

Acknowledgements The authors would like to thank Sameeksha Desai and the anonymous reviewers for their very helpful comments, criticism, and suggestions.

\section{Appendix 1}

Table 6 Country characteristics

\begin{tabular}{|c|c|c|c|c|c|c|c|c|c|}
\hline Country & $\begin{array}{l}\text { GDP per } \\
\text { capita }\end{array}$ & $\begin{array}{l}\text { GDP growth } \\
\text { per capita }\end{array}$ & Unemployment & $\begin{array}{l}\text { Market } \\
\text { opportunities }\end{array}$ & $\begin{array}{l}\text { Market } \\
\text { access }\end{array}$ & $\begin{array}{l}\text { Immigrant } \\
\text { network }\end{array}$ & $\begin{array}{l}\text { Government } \\
\text { network }\end{array}$ & $\begin{array}{l}\text { Business- } \\
\text { friendly } \\
\text { regulation }\end{array}$ & $\begin{array}{l}\text { Rule } \\
\text { of law }\end{array}$ \\
\hline Algeria & 4564.44 & 1.32 & 10.97 & 3.62 & 3.06 & 0.68 & 3.05 & 50.90 & 27.70 \\
\hline Angola & 3591.03 & 1.48 & 6.81 & 3.82 & 2.52 & 0.36 & 2.30 & 40.45 & 7.51 \\
\hline Argentina & $10,557.89$ & -2.06 & 7.22 & 3.52 & 2.76 & 4.38 & 2.91 & 56.99 & 29.58 \\
\hline Austria & $47,943.20$ & 0.29 & 4.87 & 3.29 & 3.18 & 15.20 & 3.53 & 76.71 & 97.65 \\
\hline Barbados & $15,958.93$ & -0.05 & 11.60 & 3.03 & 2.50 & 11.74 & 2.54 & 62.72 & 81.22 \\
\hline Belgium & $44,293.67$ & -0.59 & 7.54 & 3.16 & 2.90 & 9.63 & 2.98 & 74.04 & 88.73 \\
\hline $\begin{array}{l}\text { Bosnia and } \\
\text { Herzegovina }\end{array}$ & 4703.29 & 0.17 & 28.10 & 2.84 & 2.12 & 1.01 & 2.13 & 54.58 & 48.83 \\
\hline Botswana & 6779.39 & 2.56 & 17.41 & 3.18 & 2.50 & 5.90 & 2.44 & 66.65 & 70.42 \\
\hline Brazil & $11,671.18$ & 0.97 & 7.35 & 3.65 & 2.21 & 0.30 & 2.29 & 53.31 & 52.11 \\
\hline Chile & $14,109.14$ & 4.37 & 6.43 & 3.46 & 2.28 & 2.17 & 2.93 & 72.21 & 88.26 \\
\hline Colombia & 6789.53 & 2.99 & 10.43 & 3.46 & 2.59 & 0.27 & 2.93 & 69.03 & 44.60 \\
\hline Costa Rica & 8753.23 & 3.59 & 10.17 & 3.12 & 2.56 & 8.92 & 2.72 & 57.64 & 65.26 \\
\hline Croatia & $13,636.87$ & -1.89 & 15.94 & 2.74 & 2.07 & 13.28 & 2.22 & 62.98 & 60.09 \\
\hline Denmark & $58,487.79$ & -0.15 & 7.53 & 2.94 & 2.48 & 9.18 & 3.18 & 85.72 & 98.12 \\
\hline Estonia & $16,538.21$ & 4.68 & 10.02 & 3.98 & 2.78 & 16.36 & 3.01 & 75.96 & 84.51 \\
\hline Finland & $46,277.55$ & -1.89 & 7.69 & 3.68 & 2.67 & 4.62 & 2.94 & 82.05 & 99.53 \\
\hline France & $41,224.73$ & -0.30 & 9.82 & 2.76 & 2.43 & 11.43 & 3.56 & 70.49 & 90.14 \\
\hline $\begin{array}{l}\text { Gaza Strip and } \\
\text { West Bank }\end{array}$ & 2631.44 & 3.14 & 22.97 & 2.86 & 2.19 & 6.34 & 1.88 & 49.64 & 41.31 \\
\hline
\end{tabular}


Table 6 (continued)

\begin{tabular}{|c|c|c|c|c|c|c|c|c|c|}
\hline Country & $\begin{array}{l}\text { GDP per } \\
\text { capita }\end{array}$ & $\begin{array}{l}\text { GDP growth } \\
\text { per capita }\end{array}$ & Unemployment & $\begin{array}{l}\text { Market } \\
\text { opportunities }\end{array}$ & $\begin{array}{l}\text { Market } \\
\text { access }\end{array}$ & $\begin{array}{l}\text { Immigrant } \\
\text { network }\end{array}$ & $\begin{array}{l}\text { Government } \\
\text { network }\end{array}$ & $\begin{array}{l}\text { Business- } \\
\text { friendly } \\
\text { regulation }\end{array}$ & $\begin{array}{l}\text { Rule } \\
\text { of law }\end{array}$ \\
\hline Germany & $44,259.26$ & 0.30 & 5.38 & 3.13 & 2.79 & 14.43 & 3.57 & 79.59 & 92.02 \\
\hline Greece & $22,830.53$ & -6.80 & 24.44 & 2.12 & 2.17 & 11.36 & 1.71 & 60.66 & 63.85 \\
\hline Hungary & $13,144.45$ & -1.09 & 11.00 & 2.60 & 2.40 & 4.36 & 2.55 & 66.94 & 68.54 \\
\hline Ireland & $47,704.04$ & -1.32 & 14.67 & 3.29 & 2.86 & 15.82 & 3.21 & 81.54 & 94.37 \\
\hline Israel & $31,785.25$ & 0.51 & 6.86 & 3.29 & 2.74 & 26.29 & 2.63 & 71.62 & 77.93 \\
\hline Italy & $34,885.30$ & -3.08 & 10.66 & 2.72 & 2.49 & 9.71 & 2.12 & 66.83 & 62.44 \\
\hline Latvia & $12,921.14$ & 5.30 & 15.05 & 3.51 & 3.03 & 15.01 & 3.02 & 76.93 & 72.77 \\
\hline Lithuania & $13,681.00$ & 5.24 & 13.37 & 3.33 & 2.23 & 5.15 & 2.56 & 74.00 & 73.24 \\
\hline Macedonia & 4620.64 & -0.54 & 31.00 & 3.54 & 2.25 & 6.29 & 2.54 & 69.14 & 48.36 \\
\hline Malawi & 461.89 & -1.09 & 6.36 & 3.38 & 2.89 & 1.47 & 2.24 & 49.60 & 47.89 \\
\hline Malaysia & 9709.01 & 3.54 & 3.00 & 3.65 & 2.96 & 8.56 & 3.18 & 79.31 & 66.20 \\
\hline Netherlands & $50,212.96$ & -1.42 & 5.82 & 3.35 & 3.54 & 11.02 & 3.23 & 75.88 & 97.18 \\
\hline Norway & $88,585.36$ & 1.41 & 3.12 & 3.31 & 2.35 & 10.77 & 2.83 & 82.20 & 100.00 \\
\hline Pakistan & 1060.50 & 1.34 & 5.99 & 3.08 & 2.86 & 2.32 & 2.16 & 54.11 & 19.25 \\
\hline Panama & 9360.34 & 7.34 & 4.05 & 3.72 & 2.60 & 4.34 & 2.81 & 66.01 & 49.30 \\
\hline Poland & $13,436.98$ & 1.61 & 10.09 & 3.47 & 2.58 & 1.67 & 2.56 & 65.77 & 72.30 \\
\hline Portugal & $21,353.23$ & -3.64 & 15.53 & 3.00 & 2.40 & 7.21 & 2.69 & 73.42 & 82.63 \\
\hline Russia & $11,493.40$ & 3.34 & 5.46 & 3.05 & 2.12 & 7.82 & 2.16 & 56.66 & 23.94 \\
\hline Singapore & $49,103.71$ & 1.35 & 2.80 & 3.85 & 2.78 & 42.62 & 3.45 & 90.41 & 95.77 \\
\hline Slovakia & $17,299.63$ & 1.48 & 13.96 & 3.05 & 2.81 & 2.71 & 2.25 & 69.98 & 64.32 \\
\hline Slovenia & $22,859.55$ & -2.89 & 8.84 & 2.98 & 2.37 & 12.36 & 2.62 & 67.48 & 80.75 \\
\hline South Africa & 7546.81 & 0.70 & 24.73 & 3.34 & 2.19 & 3.76 & 2.10 & 68.77 & 58.22 \\
\hline Spain & $29,413.24$ & -2.99 & 24.79 & 2.91 & 2.54 & 13.48 & 2.83 & 70.13 & 83.57 \\
\hline Sweden & $52,519.68$ & -1.02 & 7.98 & 3.64 & 2.51 & 14.76 & 2.96 & 82.75 & 99.06 \\
\hline Switzerland & $74,766.63$ & -0.02 & 4.19 & 3.68 & 3.11 & 26.50 & 3.47 & 75.39 & 96.71 \\
\hline Thailand & 5437.24 & 6.75 & 0.58 & 3.26 & 2.31 & 4.83 & 2.21 & 74.96 & 50.70 \\
\hline $\begin{array}{l}\text { Trinidad and } \\
\text { Tobago }\end{array}$ & $16,680.68$ & 0.78 & 5.00 & 2.98 & 2.52 & 3.63 & 2.47 & 62.54 & 50.23 \\
\hline Turkey & $12,052.33$ & 3.16 & 8.15 & 3.52 & 2.54 & 1.89 & 2.65 & 66.04 & 57.75 \\
\hline Uganda & 631.70 & 0.38 & 1.46 & 3.95 & 2.96 & 1.60 & 2.30 & 50.42 & 46.01 \\
\hline UK & $39,226.34$ & 0.61 & 7.89 & 3.11 & 3.03 & 12.13 & 2.53 & 84.51 & 92.96 \\
\hline USA & $49,497.59$ & 1.46 & 8.10 & 3.61 & 2.73 & 14.26 & 2.70 & 85.65 & 91.55 \\
\hline Uruguay & $12,913.10$ & 3.20 & 6.44 & 3.17 & 2.82 & 2.26 & 3.03 & 61.85 & 66.67 \\
\hline Zambia & 1565.90 & 4.41 & 7.85 & 3.94 & 3.02 & 1.08 & 2.19 & 57.12 & 44.13 \\
\hline Mean & $23,167.27$ & 0.92 & 10.34 & 3.29 & 2.61 & 8.69 & 2.69 & 68.24 & 67.96 \\
\hline
\end{tabular}


Open Access This article is licensed under a Creative Commons Attribution 4.0 International License, which permits use, sharing, adaptation, distribution and reproduction in any medium or format, as long as you give appropriate credit to the original author(s) and the source, provide a link to the Creative Commons licence, and indicate if changes were made. The images or other third party material in this article are included in the article's Creative Commons licence, unless indicated otherwise in a credit line to the material. If material is not included in the article's Creative Commons licence and your intended use is not permitted by statutory regulation or exceeds the permitted use, you will need to obtain permission directly from the copyright holder. To view a copy of this licence, visit http://creativecommons.org/licenses/by/4.0/.

\section{References}

Acemoglu, D., Johnson, S., \& Robinson, J. (2005). The rise of Europe: Atlantic trade, institutional change, and economic growth. American Economic Review, 95(3), 546-579.

Acs, Z. J., Desai, S., \& Hessels, J. (2008). Entrepreneurship, economic development and institutions. Small Business Economics, 31(3), 219-234.

Aldrich, H. E., \& Waldinger, R. (1990). Ethnicity and entrepreneurship. Annual Review of Sociology, 16, 111-135.

Aliaga-Isla, R., \& Rialp, A. (2013). Systematic review of immigrant entrepreneurship literature: Previous findings and ways forward. Entrepreneurship and Regional Development, 25(9-10), 819-844.

Allen, I. E., Langowitz, N., \& Minniti, M. (2007). Global Entrepreneurship Monitor (GEM) 2006 report on women and entrepreneurship.

Altinay, L. (2008). The relationship between an entrepreneur's culture and the entrepreneurial behaviour of the firm. Journal of Small Business and Enterprise Development, 15(1), 111-129.

Amorós, J. E., Bosma, N. (2014). Global Entrepreneurship Monitor (GEM) 2013 global report.

Arenius, P., \& Minniti, M. (2005). Perceptual variables and nascent entrepreneurship. Small Business Economics, 24(3), 233-247.

Autio, E., \& Acs, Z. (2010). Intellectual property protection and the formation of entrepreneurial growth aspirations. Strategic Entrepreneurship Journal, 4(3), 234-251.

Azmat, F. (2010). Exploring social responsibility of immigrant entrepreneurs: Do home country contextual factors play a role? European Management Journal, 28(5), 377-386.

Azmat, F. (2013). Opportunities or obstacles? International Journal of Gender and Entrepreneurship, 5(2), 198-215.

Baliamoune-Lutz, M., \& Garello, P. (2014). Tax structure and entrepreneurship. Small Business Economics, 42(1), 165190.

Basu, A., \& Altinay, E. (2002). The interaction between culture and entrepreneurship in London's immigrant businesses. International Small Business Journal, 20(4), 371-393.

Bates, T. (1997). Financing small business creation: The case of Chinese and Korean immigrant entrepreneurs. Journal of Business Venturing, 12(2), 109-124.
Baughn, C. C., Chua, B. L., \& Neupert, K. E. (2006). The normative context for women's participation in entrepreneurship: A multicountry study. Entrepreneurship Theory and Practice, 30(5), 687-708.

Baycan-Levent, T., \& Nijkamp, P. (2009). Characteristics of migrant entrepreneurship in Europe. Entrepreneurship \& Regional Development, 21(4), 375-397.

Beckers, P., \& Blumberg, B. F. (2013). Immigrant entrepreneurship on the move: A longitudinal analysis of first-and secondgeneration immigrant entrepreneurship in the Netherlands. Entrepreneurship \& Regional Development, 25(7-8), 654 691.

Begley, T. M., Tan, W. L., \& Schoch, H. (2005). Politico-economic factors associated with interest in starting a business: A multicountry study. Entrepreneurship Theory and Practice, 29(1), $35-55$.

Belitski, M., Chowdhury, F., \& Desai, S. (2016). Taxes, corruption, and entry. Small Business Economics, 47(1), 201-216.

Bönte, W., \& Piegeler, M. (2013). Gender gap in latent and nascent entrepreneurship: Driven by competitiveness. Small Business Economics, 41(4), 961-987.

Borjas, G. J. (1986). The self-employment experience of immigrants. Journal of Human Resources, 21(4), 485-506.

Bosma, N., \& Levie, J. (2009). Global Entrepreneurship Monitor, 2009.

Bowen, H. P., \& de Clercq, D. (2008). Institutional context and the allocation of entrepreneurial effort. Journal of International Business Studies, 39(4), 747-767.

Caliendo, M., Fossen, F. M., \& Kritikos, A. S. (2009). Risk attitudes of nascent entrepreneurs - new evidence from an experimentally validated survey. Small Business Economics, 32(2), 153-167.

Carlsen, L., \& Bruggemann, R. (2017). Fragile state index: Trends and developments. A partial order data analysis. Social Indicators Research, 133(1), 1-14.

Carter, N. M., Williams, M., \& Reynolds, P. D. (1997). Discontinuance among new firms in retail: The influence of initial resources, strategy, and gender. Journal of Business Venturing, 12(2), 125-145.

Chen, C. C., Greene, P. G., \& Crick, A. (1998). Does entrepreneurial self-efficacy distinguish entrepreneurs from managers? Journal of Business Venturing, 13(4), 295-316.

Chowdhury, F., Terjesen, S., \& Audretsch, D. (2015). Varieties of entrepreneurship: Institutional drivers across entrepreneurial activity and country. European Journal of Law and Economics, 40(1), 121-148.

Clark, K., \& Drinkwater, S. (2010). Patterns of ethnic selfemployment in time and space: Evidence from British census microdata. Small Business Economics, 34(3), 323-338.

Collins, J., \& Low, A. (2010). Asian female immigrant entrepreneurs in small and medium-sized businesses in Australia. Entrepreneurship \& Regional Development, 22(1), 97-111.

Constant, A., \& Zimmermann, K. F. (2004). The making of entrepreneurs in Germany: Are native men and immigrants alike? IZA Discussion Paper, 1440.

De Clercq, D., Lim, D. S. K., \& Oh, C. H. (2013). Individual-level resources and new business activity: The contingent role of institutional context. Entrepreneurship Theory and Practice, 37(2), 303-330.

Desiderio, M. V. (2014). Policies to support immigrant entrepreneurship. Washington, DC: Migration Policy Institute. 
Djankov, S., La Porta, R., Lopez-De-Silanes, F., \& Shleifer, A. (2002). The regulation of entry. Quarterly Journal of Economics, 117(1), 1-37.

Djankov, S., Ganser, T., McLiesh, C., Ramalho, R., \& Shleifer, A. (2010). The effect of corporate taxes on investment and entrepreneurship. American Economic Journal: Macroeconomics, 2(3), 31-64.

Eckhardt, J. T., \& Shane, S. (2010). An update to the individualopportunity nexus. In Z. J. Acs \& D. B. Audretsch (Eds.), Handbook of entrepreneurship research (pp. 47-76). New York, NY: Springer New York.

Elam, A., \& Terjesen, S. (2010). Gendered institutions and crossnational patterns of business creation for men and women. The European Journal of Development Research, 22(3), 331-348.

Estrin, S., \& Mickiewicz, T. (2011). Institutions and female entrepreneurship. Small Business Economics, 37(4), 397-415.

Estrin, S., Mickiewicz, T., \& Stephan, U. (2013). Entrepreneurship, social capital, and institutions: Social and commercial entrepreneurship across nations. Entrepreneurship Theory and Practice, 37(3), 479-504.

Evans, D. S., \& Jovanovic, B. (1989). An estimated model of entrepreneurial choice under liquidity constraints. Journal of Political Economy, 97(4), 808-827.

Fairlie, R. W., \& Robb, A. M. (2009). Gender differences in business performance: Evidence from the characteristics of business owners survey. Small Business Economics, 33(4), 375-395.

Fiscal Policy Institute. (2012). Immigrant small business owners. Retrieved from fiscalpolicy.org/immigrant-small-businessowners-FPI-20120614.pdf

Frese, M., \& Gielnik, M. M. (2014). The psychology of entrepreneurship. Annual Review of Organizational Psychology and Organizational Behavior, 1, 413-438.

Funken, R., \& Gielnik, M. M. (2015). Entrepreneurship and aging. In N. A. Pachana (Ed.), Encyclopedia of Geropsychology (pp. 1-7). Singapore: Springer.

Gartner, W. B. (1985). A conceptual framework for describing the phenomenon of new venture creation. Academy of Management Review, 10(4), 696-706.

Hechavarría, D. M., \& Reynolds, P. D. (2009). Cultural norms \& business start-ups: The impact of national values on opportunity and necessity entrepreneurs. International Entrepreneurship and Management Journal, 5(4), 417-437.

Heilbrunn, S. (2004). Impact of gender on difficulties faced by entrepreneurs. The International Journal of Entrepreneurship and Innovation, 5(3), 159-165.

Heilbrunn, S., \& Kushnirovich, N. (2008). The impact of policy on immigrant entrepreneurship and businesses practice in Israel. International Journal of Public Sector Management, 21(7), 693-703.

Hörisch, J., Kollat, J., \& Brieger, S. (2017). What influences environmental entrepreneurship? A multilevel analysis of the determinants of entrepreneurs' environmental orientation. Small Business Economics, 48(1), 47-69.

Hox, J. (2010). Multilevel analysis: Techniques and applications. New York: Routledge.

Kaufmann, D., Kraay, A., \& Mastruzzi, M. (2011). The worldwide governance indicators: Methodology and analytical issues. Hague Journal on the Rule of Law, 3(2), 220-246.
Kautonen, T., Down, S., \& Minniti, M. (2014). Ageing and entrepreneurial preferences. Small Business Economics, 42(3), 579-594.

Kelley, D. J., Brush, C. G., Greene, P. G., \& Litovsky, Y. (2013). Global entrepreneurship monitor 2012 women's report.

Kelley, D., Brush, C. G., Patricia G., Herrington, M., Ali, A., \& Kew, P. (2015). Special report. Women's entrepreneurship.

Kloosterman, R. C. (2003). Creating opportunities. Policies aimed at increasing openings for immigrant entrepreneurs in the Netherlands. Entrepreneurship \& Regional Development, 15(2), 167-181.

Kloosterman, R., \& Rath, J. (2001). Immigrant entrepreneurs in advanced economies: Mixed embeddedness further explored. Journal of Ethnic and Migration Studies, 27(2), 189-201.

Kloosterman, R., Van der Leun, J., \& Rath, J. (1999). Mixed embeddedness: (In)formal economic activities and immigrant businesses in the Netherlands. International Journal of Urban and Regional Research, 23(2), 252-266.

Kloosterman, R. C., Rusinovic, K., \& Yeboah, D. (2016). Superdiverse migrants - similar trajectories? Ghanaian entrepreneurship in the Netherlands seen from a mixed embeddedness perspective. Journal of Ethnic and Migration Studies, 42(6), 913-932.

Klyver, K., \& Foley, D. (2012). Networking and culture in entrepreneurship. Entrepreneurship \& Regional Development, 24(7-8), 561-588.

Klyver, K., Nielsen, S. L., \& Evald, M. R. (2013). Women's selfemployment: An act of institutional (dis)integration? A multilevel, cross-country study. Journal of Business Venturing, 28(4), 474-488.

Knight, J. (2015). Migrant employment in the ethnic economy: Why do some migrants become ethnic entrepreneurs and others co-ethnic workers? Journal of International Migration and Integration, 16(3), 575-592.

Koelet, S., Van Mol, C., \& De Valk, H. A. (2017). Social embeddedness in a harmonized Europe: The social networks of European migrants with a native partner in Belgium and the Netherlands. Global Networks, 17(3), 441-459.

Koellinger, P., Minniti, M., \& Schade, C. (2007). "I think I can, I think I can": Overconfidence and entrepreneurial behavior. Journal of Economic Psychology, 28(4), 502-527.

Koellinger, P., Minniti, M., \& Schade, C. (2013). Gender differences in entrepreneurial propensity. Oxford Bulletin of Economics and Statistics, 75(2), 213-234.

Kushnirovich, N., \& Heilbrunn, S. (2008). Financial funding of immigrant businesses. Journal of Developmental Entrepreneurship, 13(2), 167-184.

Langowitz, N., \& Minniti, M. (2007). The entrepreneurial propensity of women. Entrepreneurship Theory and Practice, 31(3), 341-364.

Lassalle, P., \& McElwee, G. (2016). Polish entrepreneurs in Glasgow and entrepreneurial opportunity structure. International Journal of Entrepreneurial Behavior \& Research, 22(2), 260-281.

Lassmann, A., \& Busch, C. (2015). Revisiting native and immigrant entrepreneurial activity. Small Business Economics, 45(4), 841-873.

Levie, J. (2007). Immigration, in-migration, ethnicity and entrepreneurship in the United Kingdom. Small Business Economics, 28(2-3), 143-169. 
Levie, J., \& Autio, E. (2008). A theoretical grounding and test of the GEM model. Small Business Economics, 31(3), 235-263.

Lofstrom, M., \& Lofstrom, M. (2014). Immigrants and entrepreneurship. IZA World of Labor, 14, 1-10.

Lüthje, C., \& Franke, N. (2003). The 'making' of an entrepreneur: Testing a model of entrepreneurial intent among engineering students at MIT. $R$ and D Management, 33(2), 135-147.

Maas, C. J. M., \& Hox, J. J. (2004). Robustness issues in multilevel regression analysis. Statistica Neerlandica, 58(2), 127137.

Marchand, K. \& Siegel, M. (2014). World migration report 2015: Immigrant entrepreneurship in cities. Retrieved from iom. int/sites/default/files/our_work/ICP/MPR/WMR-2015Background-Paper-KMarchand-MSiegel.pdf

Marlow, S., \& Patton, D. (2005). All credit to men? Entrepreneurship, finance, and gender. Entrepreneurship Theory and Practice, 29(6), 717-735.

Martínez-Fierro, S., Biedma-Ferrer, J. M., \& Ruiz-Navarro, J. (2016). Entrepreneurship and strategies for economic development. Small Business Economics, 47(4), 835-851.

McEvoy, D., \& Hafeez, K. (2009a). Ethnic enclaves or middleman minority? Regional patterns of ethnic minority entrepreneurship in Britain. International Journal of Business and Globalisation, 3(1), 94-110.

McEvoy, D., \& Hafeez, K. (2009b). Ethnic minority entrepreneurship in Britain. Management \& Marketing, 4(1), 55-64.

McMullen, J. S., Bagby, D. R., \& Palich, L. E. (2008). Economic freedom and the motivation to engage in entrepreneurial action. Entrepreneurship Theory and Practice, 32(5), 875895.

Mikucka, M. (2014). Does individualistic culture lower the wellbeing of the unemployed? Evidence from Europe. Journal of Happiness Studies, 15(3), 673-691.

Minniti, M. (2010). Female entrepreneurship and economic activity. The European Journal of Development Research, 22(3), 294-312.

Minniti, M., \& Nardone, C. (2007). Being in someone else's shoes: The role of gender in nascent entrepreneurship. Small Business Economics, 28(2-3), 223-238.

Minniti, M., \& Naudé, W. (2010). What do we know about the patterns and determinants of female entrepreneurship across countries? The European Journal of Development Research, 22(3), 277-293.

Minola, T., Criaco, G., \& Obschonka, M. (2016). Age, culture, and self-employment motivation. Small Business Economics, 46(2), 187-213.

Mueller, S. L. (2004). Gender gaps in potential for entrepreneurship across countries and cultures. Journal of Developmental Entrepreneurship, 9(3), 199-220.

Muravyev, A., Talavera, O., \& Schäfer, D. (2009). Entrepreneurs' gender and financial constraints: Evidence from international data. Journal of Comparative Economics, 37(2), 270-286.

Noguera, M., Alvarez, C., \& Urbano, D. (2013). Socio-cultural factors and female entrepreneurship. International Entrepreneurship and Management Journal, 9(2), 183-197.

OECD (2011). International migration outlook 2011. Paris: Organisation for Economic Co-operation and Development.

OECD/European Commission (2015). Indicators of immigrant integration 2015: Settling in. Retrieved from http://www. oecd.org/els/mig/Indicators-of-Immigrant-Integration-2015. pdf.
Peroni, C., Riillo, C. A. F., \& Sarracino, F. (2016). Entrepreneurship and immigration: Evidence from GEM Luxembourg. Small Business Economics, 46(4), 639-656.

Pruett, M., Shinnar, R., Toney, B., Llopis, F., \& Fox, J. (2009). Explaining entrepreneurial intentions of university students: A cross-cultural study. International Journal of Entrepreneurial Behavior \& Research, 15(6), 571-594.

Rath, J., \& Kloosterman, R. (2000). Outsiders' business: A critical review of research on immigrant entrepreneurship. International Migration Review, 34(3), 657-681.

Rauch, A., \& Frese, M. (2007). Let's put the person back into entrepreneurship research: A meta-analysis on the relationship between business owners' personality traits, business creation, and success. European Journal of Work and Organizational Psychology, 16(4), 353-385.

Saxenian, A. (2002). Silicon Valley's new immigrant high-growth entrepreneurs. Economic Development Quarterly, 16(1), 2031.

Shane, S., \& Venkataraman, S. (2000). The promise of entrepreneurship as a field of research. Academy of Management Review, 25(1), 217-226.

Shinnar, R. S., \& Young, C. A. (2008). Hispanic immigrant entrepreneurs in the Las Vegas metropolitan area: Motivations for entry into and outcomes of self-employment. Journal of Small Business Management, 46(2), 242-262.

Shinnar, R. S., Giacomin, O., \& Janssen, F. (2012). Entrepreneurial perceptions and intentions: The role of gender and culture. Entrepreneurship Theory and Practice, 36(3), 465-493.

Snijders, T. A. B., \& Bosker, R. J. (2012). Multilevel analysis: An introduction to basic and advanced multilevel modeling (2nd ed.). Los Angeles, CA: Sage.

Stam, W., Arzlanian, S., \& Elfring, T. (2014). Social capital of entrepreneurs and small firm performance: A meta-analysis of contextual and methodological moderators. Journal of Business Venturing, 29(1), 152-173.

Stephan, U., \& Uhlaner, L. M. (2010). Performance-based vs socially supportive culture: A cross-national study of descriptive norms and entrepreneurship. Journal of International Business Studies, 41(8), 1347-1364.

Sternberg, R., \& Wennekers, S. (2005). Determinants and effects of new business creation using Global Entrepreneurship Monitor data. Small Business Economics, 24(3), 193-203.

Terjesen, S., Bosma, N., \& Stam, E. (2016). Advancing public policy for high-growth, female, and social entrepreneurs. Public Administration Review, 76(2), 230-239.

Thébaud, S. (2010). Gender and entrepreneurship as a career choice: Do self-assessments of ability matter? Social Psychology Quarterly, 73(3), 288-304.

Thébaud, S. (2015). Business as Plan B: Institutional foundations of gender inequality in entrepreneurship across 24 industrialized countries. Administrative Science Quarterly, 60(4), 671-711.

UN Refugee Agency (2018). Refugee statistics. Retrieved from https://www.unrefugees.org/refugee-facts/statistics.

Unger, J. M., Rauch, A., Frese, M., \& Rosenbusch, N. (2011). Human capital and entrepreneurial success: A metaanalytical review. Journal of Business Venturing, 26(3), 341-358. 
Urbano, D., \& Alvarez, C. (2014). Institutional dimensions and entrepreneurial activity: An international study. Small Business Economics, 42(4), 703-716.

Vaccarino, F., Tremaine, M., Anast, J., \& Robotis, P. (2011). Female immigrant entrepreneurs: The economic and social impact of a global phenomenon. In D. Halkias, P. Thurman, $\&$ N. Harkiolakis (Eds.), Female immigrant entrepreneurs. The economic and social impact of a global phenomenon (pp. 71-87). Farnham, Surrey, England: Gower.

van der Zwan, P., Verheul, I., \& Thurik, A. R. (2012). The entrepreneurial ladder, gender, and regional development. Small Business Economics, 39(3), 627-643.

Verheul, I., \& Thurik, R. (2001). Start-up capital: "Does gender matter?". Small Business Economics, 16(4), 329-346.

Verheul, I., Van Stel, A., \& Thurik, R. (2006). Explaining female and male entrepreneurship at the country level. Entrepreneurship \& Regional Development, 18(2), 151-183.

Wagner, J. (2007). What a difference a Y makes — female and male nascent entrepreneurs in Germany. Small Business Economics, 28(1), 1-21.

Wang, Y., \& Warn, J. (2017). Chinese immigrant entrepreneurship: Embeddedness and the interaction of resources with the wider social and economic and context. Online First: International Small Business Journal.

Welter, F. (2010). Contextualizing entrepreneurship — conceptual challenges and ways forward. Entrepreneurship Theory and Practice, 35(1), 165-184.
Welter, F., \& Smallbone, D. (2011). Institutional perspectives on entrepreneurial behavior in challenging environments. Journal of Small Business Management, 49(1), 107-125.

Wennberg, K., Pathak, S., \& Autio, E. (2013). How culture moulds the effects of self-efficacy and fear of failure on entrepreneurship. Entrepreneurship \& Regional Development, 25(9-10), 756-780.

Wilson, F., Kickul, J., \& Marlino, D. (2007). Gender, entrepreneurial self-efficacy, and entrepreneurial career intentions: Implications for entrepreneurship education. Entrepreneurship Theory and Practice, 31(3), 387-406.

Wilson, F., Kickul, J., Marlino, D., Barbosa, S. D., \& Griffiths, M. D. (2009). An analysis of the role of gender and self-efficacy in developing female entrepreneurial interest and behavior. Journal of Developmental Entrepreneurship, 14(2), 105119.

Xavier, S. R., Kelley, D., Kew, J., Herrington, M., \& Vorderwülbecke, A. (2012). Global Entrepreneurship Monitor, 2012.

Publisher's note Springer Nature remains neutral with regard to jurisdictional claims in published maps and institutional affiliations. 